\title{
Bright oligothiophene N-succinimidyl esters for efficient fluorescent labeling of proteins and oligonucleotides
}

Giovanna Barbarella, ${ }^{* \S}$ Massimo Zambianchi, ${ }^{\S}$ Alfredo Ventola, ${ }^{\&}$ Eduardo Fabiano,"

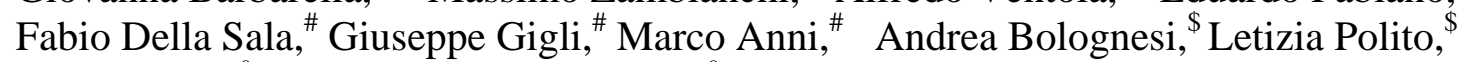
Marina Naldi ${ }^{\S}$ and Massimo Capobianco ${ }^{\S}$

Consiglio Nazionale Ricerche (ISOF), Mediteknology srl, Area Ricerca CNR, Via Gobetti 101, I-40129 Bologna, Italy, National Nanotechnology Laboratory (NNL), Distretto Tecnologico, Via Arnesano, I-73100 Lecce, Italy, and Dipartimento di Patologia Sperimentale, Università di Bologna, Via San Giacomo, 14, I-40126 Bologna, Italy

\section{SUPPORTING INFORMATION}

1. Synthesis of compounds 2-3, 6d, 8b, 10, 14: pages 2-4

2. Absorption spectra of the conjugates of IgG1 isotype antibody with FITC: pages 5-6

3. Absorption spectra of the conjugates of IgG1 isotype antibody with compound 9: pages 7-10

4. Photograph of the separation by size exclusion chromatography of the conjugate of IgG1 antiCD3 antibody labeled with compound 9 from the free fluorophore under irradiation with a $15 \mathrm{~W}$ lamp at $\lambda_{\text {exc }}=364 \mathrm{~nm}$ : page 11 
Synthesis. The synthetic pattern for the preparation of compounds $\mathbf{3}, \mathbf{6 d}$ and $\mathbf{8 b}$ is described in Schemes 1-4. 5-Bromo-2-thiophene-carboxaldehyde (1), 2-(tributylstannyl)-thiophene (4), 2-(2thienyl)ethanol (6a), 2-(methylthio)thiophene (8a), N-hydroxysuccinimide (HOSu), N,N'dicyclohexylcarbo-diimide (DCC), 2-methoxylethoxylmethyl chloride (MEMCl), N,Ndiisopropylethylamine, 4-dimethylaminopyridine (DMAP), N-bromosuccinimide (NBS), $n$ butyllithium, tributyltin chloride, tris(dibenzylideneaceton)-dipalladium(0)-chloroform adduct and triphenylarsine are commercially available compounds.

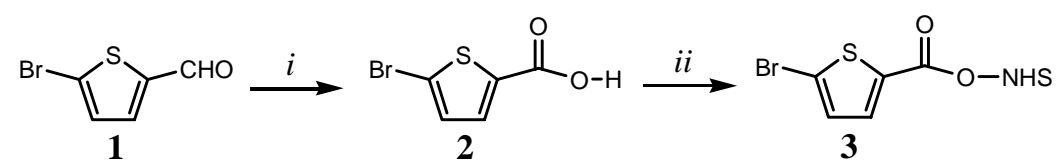

Scheme 2. Reagents and conditions: (i) Jones reagent, aceton, $15 \mathrm{~min}, 0^{\circ} \mathrm{C}$; (ii) HOSu, DCC, THF, 2 h, r.t.

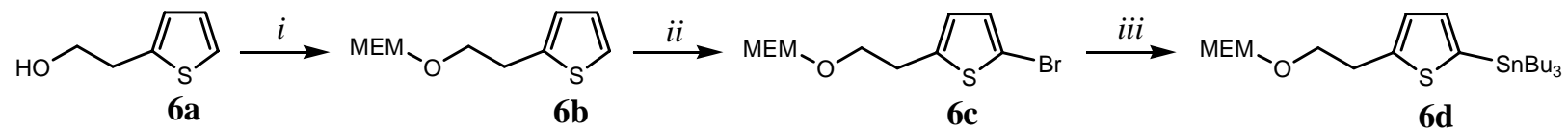

Scheme 3. Reagents and conditions: (i) MEMCl, N,N-diisopropylethylamine, DMAP, $\mathrm{CH}_{2} \mathrm{Cl}_{2}, 12$ h, r.t.; (ii) $\mathrm{NBS}, \mathrm{CH}_{2} \mathrm{Cl}_{2}, 3$ h, r.t.; (iii) n-BuLi, $\mathrm{Et}_{2} \mathrm{O}, 2$ h, r.t.; $\mathrm{Bu}_{3} \mathrm{SnCl}, 30$ min., r.t.

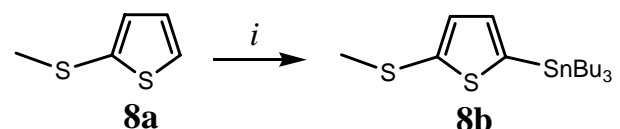

Scheme 4. Reagents and conditions: (i) n-BuLi, $\mathrm{Et}_{2} \mathrm{O}, 2$ h, r.t.; $\mathrm{Bu}_{3} \mathrm{SnCl}$, 30 min, r.t.

2-Bromo-thiophene-5-carboxylic acid, 2. To a $50 \mathrm{~mL}$ acetone solution of 1 (9.84 g, $6.11 \mathrm{~mL}, 0.05$ mol) was added dropwise the freshly prepared Jones reagent $\left(\mathrm{CrO}_{3}\right.$, aq. $\mathrm{H}_{2} \mathrm{SO}_{4}, 2.67 \mathrm{M}, 20.6 \mathrm{~mL}$, $0.055 \mathrm{~mol}$ ) at $0{ }^{\circ} \mathrm{C}$. The resulting mixture was allowed to react at this temperature for $1 \mathrm{~h}$, then aq. $\mathrm{NaHSO}_{3}(5 \mathrm{~mL})$ was added. The precipitated green chromium salt was removed by filtration and the solvent was evaporated under reduced pressure. The resulting crude product was dissolved in ethyl acetate $(100 \mathrm{~mL})$ and washed with brine $(2 \times 50 \mathrm{~mL})$. The solvent was removed in vacuo, and the remaining residue was purified by recrystallization from ethanol/water to give $9.42 \mathrm{~g}$ (91\% yield) of the title compound as a white crystalline solid, mp 138-139 ${ }^{\circ} \mathrm{C}$ [literature (1): $\mathrm{mp} 136{ }^{\circ} \mathrm{C}$ ]; 
EI-MS m/z $208\left(\mathrm{M}^{+}\right) .{ }^{1} \mathrm{H}$ NMR $\left(\mathrm{CDCl}_{3}, \mathrm{TMS} / \mathrm{ppm}\right) \delta 11.45$ (broad singlet, $\left.\mathrm{COOH}\right), 7.64$ (d, ${ }^{3} J=4.0$ $\mathrm{Hz}, 1 \mathrm{H}), 7.11$ (dd, $\left.{ }^{3} J=4.0 \mathrm{~Hz}, 1 \mathrm{H}\right) ;{ }^{13} \mathrm{C} \mathrm{NMR}\left(\mathrm{CDCl}_{3}, \mathrm{TMS} / \mathrm{ppm}\right) \delta 166.73,135.35,133.79,131.28$, 122.29.

5-Bromo-thiophene-2-carboxylic acid 2,5-dioxo-pyrrolidin-1-yl ester, 3. A mixture of 2 (3.10 g, 15 mmol), N-hydroxysuccinimide (1.76 g, 15 mmol) and N,N'-dicyclohexylcarbodiimide (3.18 g, 15.3 mmol) in dry THF (35 mL) was stirred at ambient temperature for $12 \mathrm{~h}$. The solid was filtered off and washed with dry THF, and the filtrate was evaporated in vacuo. The crude product was purified by recrystallization from methylene chloride/pentane to afford $4.12 \mathrm{~g}$ (90\%) of 3 (white solid), mp 147-148 ${ }^{\circ} \mathrm{C}$; $\delta$ EI-MS m/z $305\left(\mathrm{M}^{+}\right)$; absorption maximum, $290 \mathrm{~nm}$ in $\mathrm{CH}_{2} \mathrm{Cl}_{2}$; ${ }^{1} \mathrm{H}$ NMR (400 MHz, $\left.\mathrm{CDCl}_{3}, \mathrm{TMS} / \mathrm{ppm}\right) \delta$ 7.76, (d, $\left.{ }^{3} J=4.4 \mathrm{~Hz}, 1 \mathrm{H}\right), 7.16\left(\mathrm{~d},{ }^{3} \mathrm{~J}=4.4 \mathrm{~Hz}, 1 \mathrm{H}\right), 2.88(\mathrm{~s}, 4 \mathrm{H}) ;{ }^{13} \mathrm{C}$ NMR (400 MHz, $\left.\mathrm{CDCl}_{3}, \mathrm{TMS} / \mathrm{ppm}\right) \delta$ 168.97, 156.19, 136.97, 131.55, 127.94, 124.21, 25.55.

5-Tributylstannyl-5'-[2-(2-methoxy-ethoxymethoxy)-ethyl]thiophene, 6d. To a mixture of 2-(2thienyl)ethanol, 6a (1.28 g, $1.11 \mathrm{~mL}, 0.01 \mathrm{~mol})$, N,N-diisopropylethylamine (1.87 g, $1.72 \mathrm{~mL}$, $0.015 \mathrm{mmol}$ ), and DMAP (some $\mathrm{mg}$ ) in dichloromethane $(12 \mathrm{~mL}$ ) was added dropwise $\mathrm{MEMCl}$ at room temperature. The mixture was stirred overnight, then quenched with aq. $\mathrm{NaHCO}_{3}(50 \mathrm{~mL})$. After separation of the layers, the aqueous phase was extracted with $\mathrm{CH}_{2} \mathrm{Cl}_{2}$. The resulting organic layers were dried over $\mathrm{Na}_{2} \mathrm{SO}_{4}$. Evaporation of solvent gave $2.02 \mathrm{~g}$ (93\% yield) of $\mathbf{6 b}$ (colorless oil). The product was used as such for next step: EI-MS $\mathrm{m} / \mathrm{z} 216\left(\mathrm{M}^{+}\right)$; absorption maximum, 244 $\mathrm{nm}$ in $\mathrm{CH}_{2} \mathrm{Cl}_{2}$; ${ }^{1} \mathrm{H}$ NMR $\left(\mathrm{CDCl}_{3}\right.$, TMS/ppm) $\delta 7.12(\mathrm{~m}, 1 \mathrm{H}), 6.91(\mathrm{~m}, 1 \mathrm{H}), 6.84(\mathrm{~m}, 1 \mathrm{H}), 4.73$ (s, 2H), 3.79 (t, $\left.{ }^{3} \mathrm{~J}=6.8 \mathrm{~Hz}, 2 \mathrm{H}\right), 3.63$ (m, 2H), 3.51 (m, 2H), 3.37 (s, 3H), $3.10\left(\mathrm{t},{ }^{3} \mathrm{~J}=6.8 \mathrm{~Hz}, 2 \mathrm{H}\right) ;{ }^{13} \mathrm{C}$ NMR $\left(\mathrm{CDCl}_{3}, \mathrm{TMS} / \mathrm{ppm}\right) \delta 141.10,126.54,125.02,123.49,95.33,71.60,68.21,66.66,58.85$, 30.32. Compound $\mathbf{6 b}(0.82 \mathrm{~g}, 3.80 \mathrm{mmol})$ was reacted with an equimolar amount of $\mathrm{NBS}$ in $\mathrm{CH}_{2} \mathrm{Cl}_{2}$ $(20 \mathrm{~mL})$ and stirred for $3 \mathrm{~h}$ at room temperature. The solvent was removed by rotary evaporation and the remaining residue was purified by flash chromatography $\left(\mathrm{SiO}_{2}\right.$, petroleum ether/ethyl acetate 7:3) to provide 1.03 g (85\% yield) of compound 6c as a light yellow oil: EI-MS m/z 295 $\left(\mathrm{M}^{+}\right)$; absorption maximum, $243 \mathrm{~nm}$ in $\mathrm{CH}_{2} \mathrm{Cl}_{2} ;{ }^{1} \mathrm{H}$ NMR $\left(\mathrm{CDCl}_{3}, \mathrm{TMS} / \mathrm{ppm}\right) \delta 6.83\left(\mathrm{~d},{ }^{3} \mathrm{~J}=4.0 \mathrm{~Hz}\right.$, 1H), 6.58 (m, 1H), 4.71 (s, 2H), 3.73 (t, ${ }^{3} J=6.4$ Hz, 2H), 3.64 (m, 2H), 3.51 (m, 2H), 3.36 (s, 3H), $3.00\left(\mathrm{t},{ }^{3} \mathrm{~J}=6.4 \mathrm{~Hz}, 2 \mathrm{H}\right) ;{ }^{13} \mathrm{C} \mathrm{NMR}\left(\mathrm{CDCl}_{3}, \mathrm{TMS} / \mathrm{ppm}\right) \delta 143.12,129.20,125.49,109.54,95.39$, 71.59, 67.74, 66.79, 58.89, 30.83. To a solution of $6 \mathrm{c}(0.74 \mathrm{~g}, 2.50 \mathrm{mmol})$ in dry $\mathrm{Et}_{2} \mathrm{O}(6 \mathrm{~mL})$ was added $n$-BuLi (2.5 M in hexane, $1 \mathrm{~mL}, 2.50 \mathrm{mmol})$ at room temperature. After $2 \mathrm{~h}$, tributyltin chloride (0.81 g, $0.68 \mathrm{~mL}, 2.50 \mathrm{mmol}$ ) was added dropwise. The reaction mixture was stirred 30 min at room temperature. The solvent was removed in vacuo and the crude product was purified by chromatography (aluminium oxide, petroleum ether/ethyl acetate 7:3) to provide $1.11 \mathrm{~g}$ (88\% yield) of compound $\mathbf{6 d}$ as a clear colorless oil: EI-MS m/z $505\left(\mathrm{M}^{+}\right)$; absorption maximum, $246 \mathrm{~nm}$ in 
$\mathrm{CH}_{2} \mathrm{Cl}_{2} ;{ }^{1} \mathrm{H}$ NMR $\left(\mathrm{CDCl}_{3}\right.$, TMS/ppm) $\delta 6.98(\mathrm{~m}, 2 \mathrm{H}), 4.75$ (s, 2H), $3.82\left(\mathrm{t},{ }^{3} \mathrm{~J}=6.8 \mathrm{~Hz}, 2 \mathrm{H}\right), 3.66$ (m, 2H), 3.53 (m, 2H), 3.39 (s, 3H), $3.16\left(\mathrm{t},{ }^{3} \mathrm{~J}=6.8 \mathrm{~Hz}, 2 \mathrm{H}\right), 1.58$ (m, 6H), 1.38 (m, 6H), 1.06 (m,

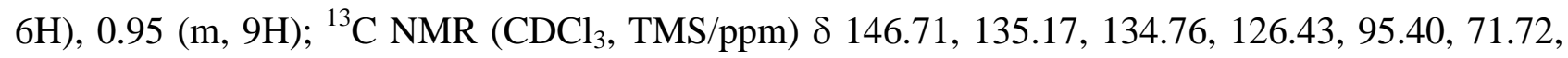
68.39, 66.71, 58.95, 30.38, 28.89, 27.21, 13.62, 10.66.

5-Tributylstannyl-5'-methylsulfanyl-thiophene, 8b. This compound was quantitatively obtained from 2-(methylthio)thiophene, 8a (1.30 g, $0.01 \mathrm{~mol})$ as described for compound $\mathbf{6 d}$. The crude product was virtually pure by ${ }^{1} \mathrm{H}$ NMR and was used without further purification for next step. Product 8b: clear yellow-amber oil; EI-MS m/z $420\left(\mathrm{M}^{+}\right) ;{ }^{1} \mathrm{H}$ NMR $\left(\mathrm{CDCl}_{3}, \mathrm{TMS} / \mathrm{ppm}\right) \delta 7.15$ (d, $\left.{ }^{3} J=3.6 \mathrm{~Hz}, 1 \mathrm{H}\right), 7.02$ (d, $\left.{ }^{3} J=3.6 \mathrm{~Hz}, 1 \mathrm{H}\right), 2.50$ (s, 3H), 1.55 (m, 6H), 1.33 (m, 6H), 1.09 (m, 6H), 0.90 (m, 9H); ${ }^{13} \mathrm{C} \mathrm{NMR}\left(\mathrm{CDCl}_{3}, \mathrm{TMS} / \mathrm{ppm}\right) \delta 141.95,140.28,135.65,131.20,28.89,27.22,21.90$, 13.64, 10.81 .

5'-Bromo-[2,2']bithiophenyl-5-carboxylic acid 2,5-dioxo-pyrrolidin-1-yl ester, 10. Under exclusion of ligth $N$-bromosuccinimide (2.67 g, $15 \mathrm{mmol}$ ) was added stepwise to a solution of 5 (1.53 g, 5 $\mathrm{mmol})$ in dichloromethane $(50 \mathrm{~mL})$. The mixture was left to stir overnight at room temperature then quenched with ice. After separation of layers, the aqueous phase was extracted with $\mathrm{CH}_{2} \mathrm{Cl}_{2}$. The resulting organic layers were washed sequentially with $10 \% \mathrm{NaHCO}_{3 \mathrm{aq}}(2 \times 50 \mathrm{~mL})$ and $10 \% \mathrm{KOH}_{\mathrm{aq}}$ (2x50 mL). The organic layer was dried over anhydrous sodium sulfate and the solvent was removed by rotary evaporation. The product was utilized without further purification. Yield: $1.47 \mathrm{~g}$ (73\%). Polycrystalline pale yellow solid, mp 227-228 ${ }^{\circ} \mathrm{C}$; EI-MS $\mathrm{m} / \mathrm{z} 387\left(\mathrm{M}^{+}\right) ;{ }^{1} \mathrm{H}$ NMR $\left(\mathrm{CDCl}_{3}\right.$, TMS/ppm) $\delta 7.91$ (d, $\left.{ }^{3} J=4.4 \mathrm{~Hz}, 1 \mathrm{H}\right), 7.16$ (d, $\left.{ }^{3} J=4.4 \mathrm{~Hz}, 1 \mathrm{H}\right), 7.09$ (d, $\left.{ }^{3} J=4.0 \mathrm{~Hz}, 1 \mathrm{H}\right), 7.04$ (d, $\left.{ }^{3} J=4.0 \mathrm{~Hz}, 1 \mathrm{H}\right), 2.90$ (s, 4H); ${ }^{13} \mathrm{C} \mathrm{NMR}\left(\mathrm{CDCl}_{3}, \mathrm{TMS} / \mathrm{ppm}\right) \delta 169.03,157.02,146.39,137.48$, 136.86, 131.19, 126.29, 124.67, 124.43, 114.27, 25.63.

5"-Bromo-[2,2';5',2"]terthiophene-5-carboxylic acid 2,5-dioxo-pyrrolidin-1-yl ester, 14. Under exclusion of ligth $N$-bromosuccinimide (98 mg, $0.55 \mathrm{mmol}$ ) was added stepwise to a solution of 11 (195 mg, $0.5 \mathrm{mmol})$ in dichloromethane $(15 \mathrm{~mL})$. The mixture was left to stir overnight at room temperature then quenched with ice. The work-up procedure was the same as for compound 10, and $225 \mathrm{mg}$ of a polycrystalline amber solid (96\% yield) was recovered, mp 213-214 ${ }^{\circ} \mathrm{C}$; EI-MS $\mathrm{m} / \mathrm{z}$ $469\left(\mathrm{M}^{+}\right) ;{ }^{1} \mathrm{H}$ NMR $\left(\mathrm{CDCl}_{3}, \mathrm{TMS} / \mathrm{ppm}\right) \delta 7.91$ (d, $\left.{ }^{3} J=4.0 \mathrm{~Hz}, 1 \mathrm{H}\right), 7.23$ (d, $\left.{ }^{3} J=4.0 \mathrm{~Hz}, 1 \mathrm{H}\right), 7.19$ (d, ${ }^{3} J=4.0 \mathrm{~Hz}, 1 \mathrm{H}$ ), 7.05 (d, $\left.{ }^{3} J=4.0 \mathrm{~Hz}, 1 \mathrm{H}\right), 6.99$ (d, $\left.{ }^{3} J=4.0 \mathrm{~Hz}, 1 \mathrm{H}\right), 6.95$ (d, $\left.{ }^{3} J=4.0 \mathrm{~Hz}, 1 \mathrm{H}\right), 2.89$ (s, $4 \mathrm{H}) ;{ }^{13} \mathrm{C} \mathrm{NMR}\left(\mathrm{CDCl}_{3}, \mathrm{TMS} / \mathrm{ppm}\right) \delta 169.08,157.04,144.03,137.99,137.74,137.57,134.36$, 130.87, 126.90, 124.87, 124.59, 124.30, 124.26, 112.17, 25.63. 


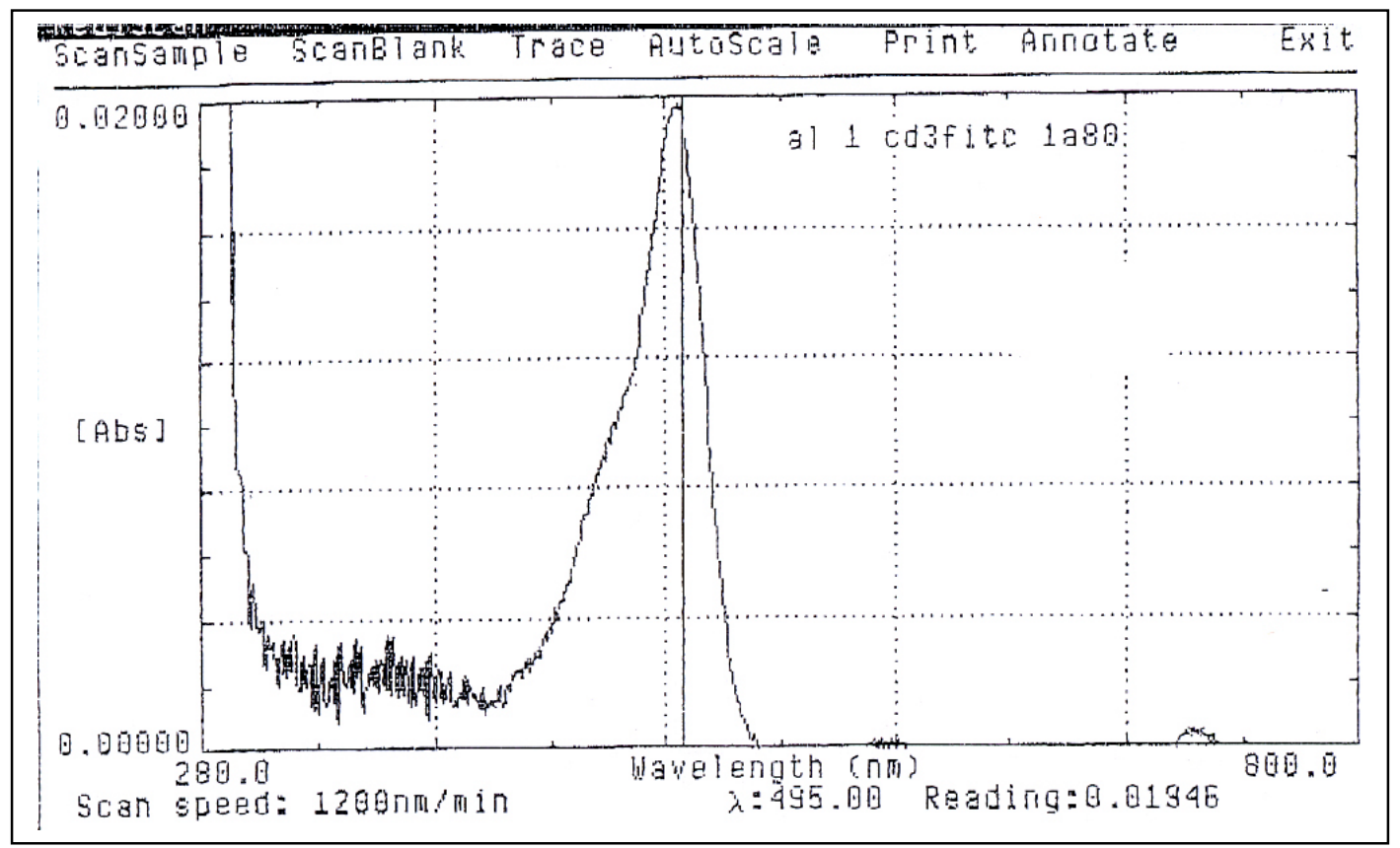

Figure 1S. Absorption spectrum of the conjugate of IgG1 isotype antibody with FITC ( $\mathrm{F} / \mathrm{P}=7$, dilution $1: 80)$ after stabilizing with $0.5 \% \mathrm{BSA} / 0.1 \%$ sodium azide $(\mathrm{w} / \mathrm{v})$.

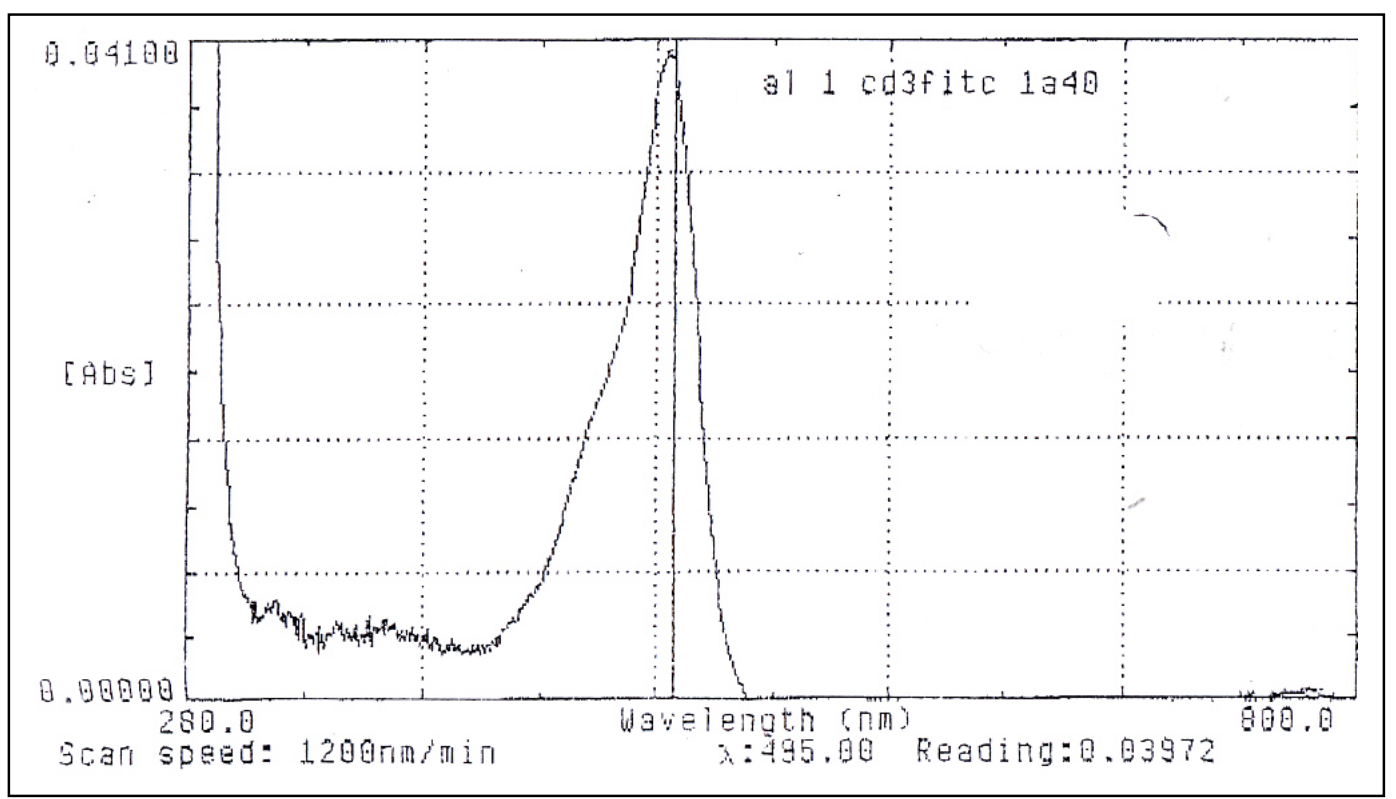

Figure 2S. Absorption spectrum of the conjugate of IgG1 isotype antibody with FITC $(\mathrm{F} / \mathrm{P}=7$, dilution $1: 40)$ after stabilizing with $0.5 \% \mathrm{BSA} / 0.1 \%$ sodium azide $(\mathrm{w} / \mathrm{v})$. 


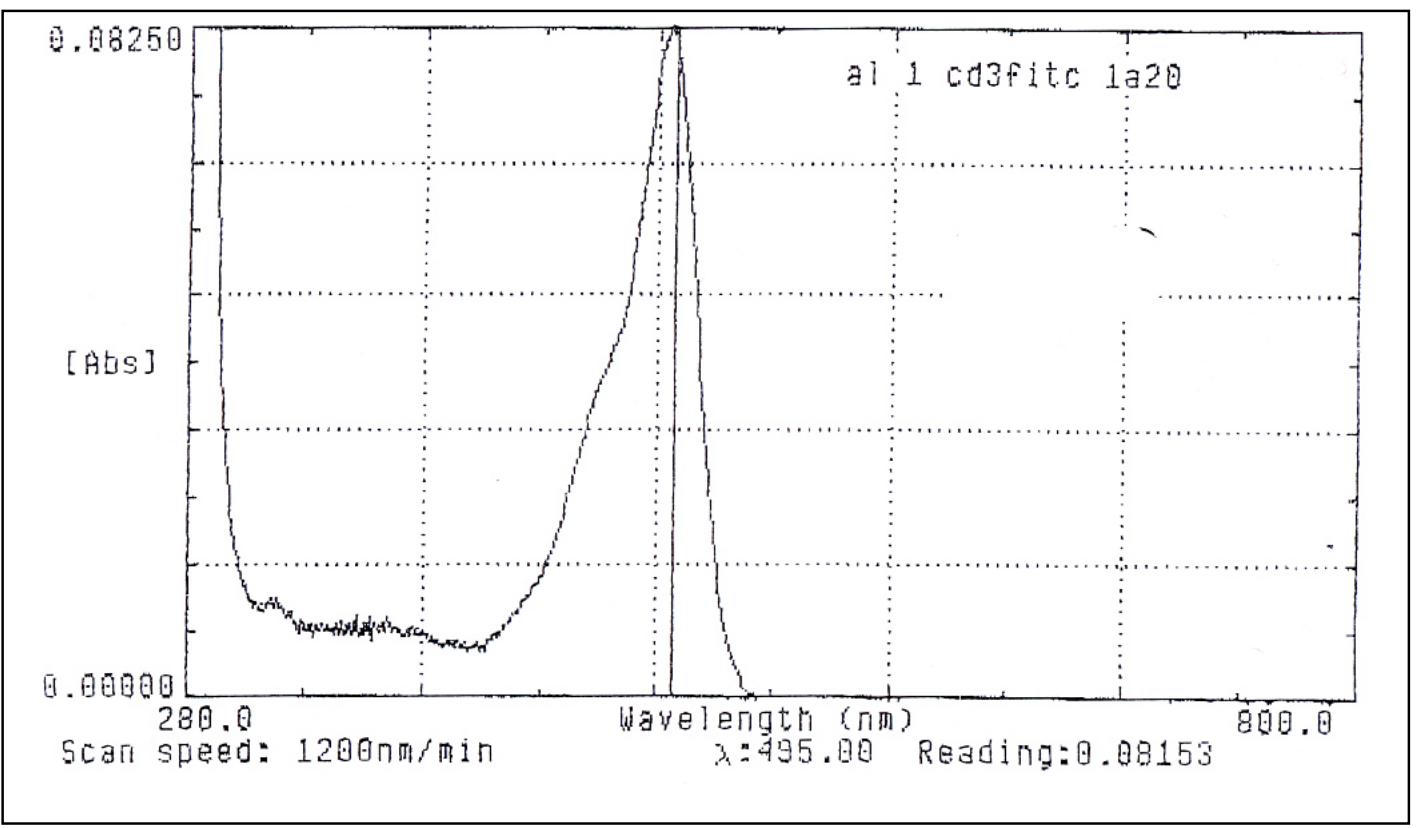

Figure 3S. Absorption spectrum of the conjugate of IgG1 isotype antibody with FITC ( $\mathrm{F} / \mathrm{P}=7$, dilution $1: 20)$ after stabilizing with $0.5 \% \mathrm{BSA} / 0.1 \%$ sodium azide $(\mathrm{w} / \mathrm{v})$.

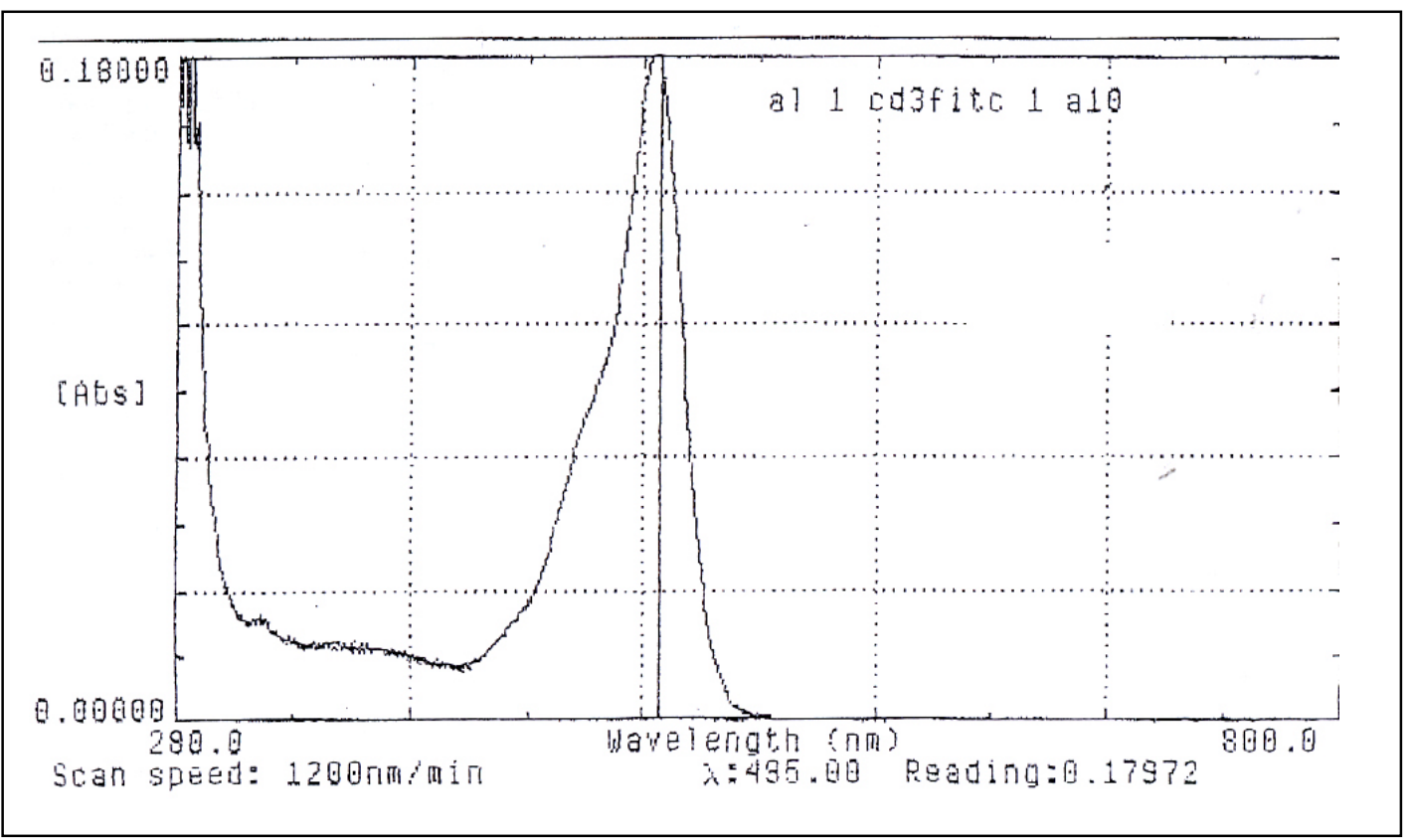

Figure 4S. Absorption spectrum of the conjugate of IgG1 isotype antibody with FITC ( $\mathrm{F} / \mathrm{P}=7$, dilution $1: 10$ ) after stabilizing with $0.5 \% \mathrm{BSA} / 0.1 \%$ sodium azide $(\mathrm{w} / \mathrm{v})$. 


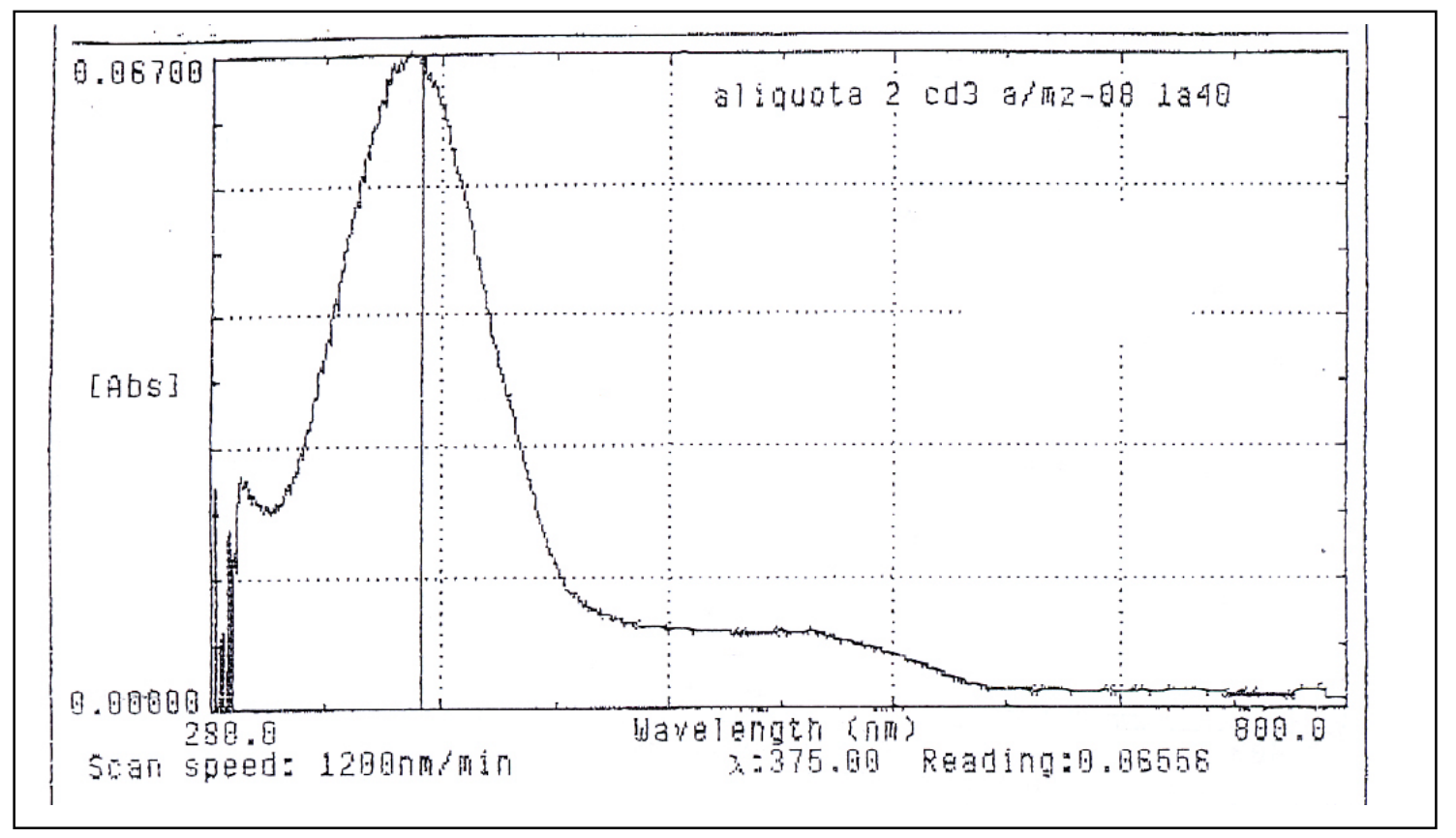

Figure 5S. Absorption spectrum of the conjugate of IgG1 isotype antibody with compound 9 ( $\mathrm{F} / \mathrm{P}=6.7$, dilution $1: 40)$ after stabilizing with $0.5 \% \mathrm{BSA} / 0.1 \%$ sodium azide $(\mathrm{w} / \mathrm{v})$.

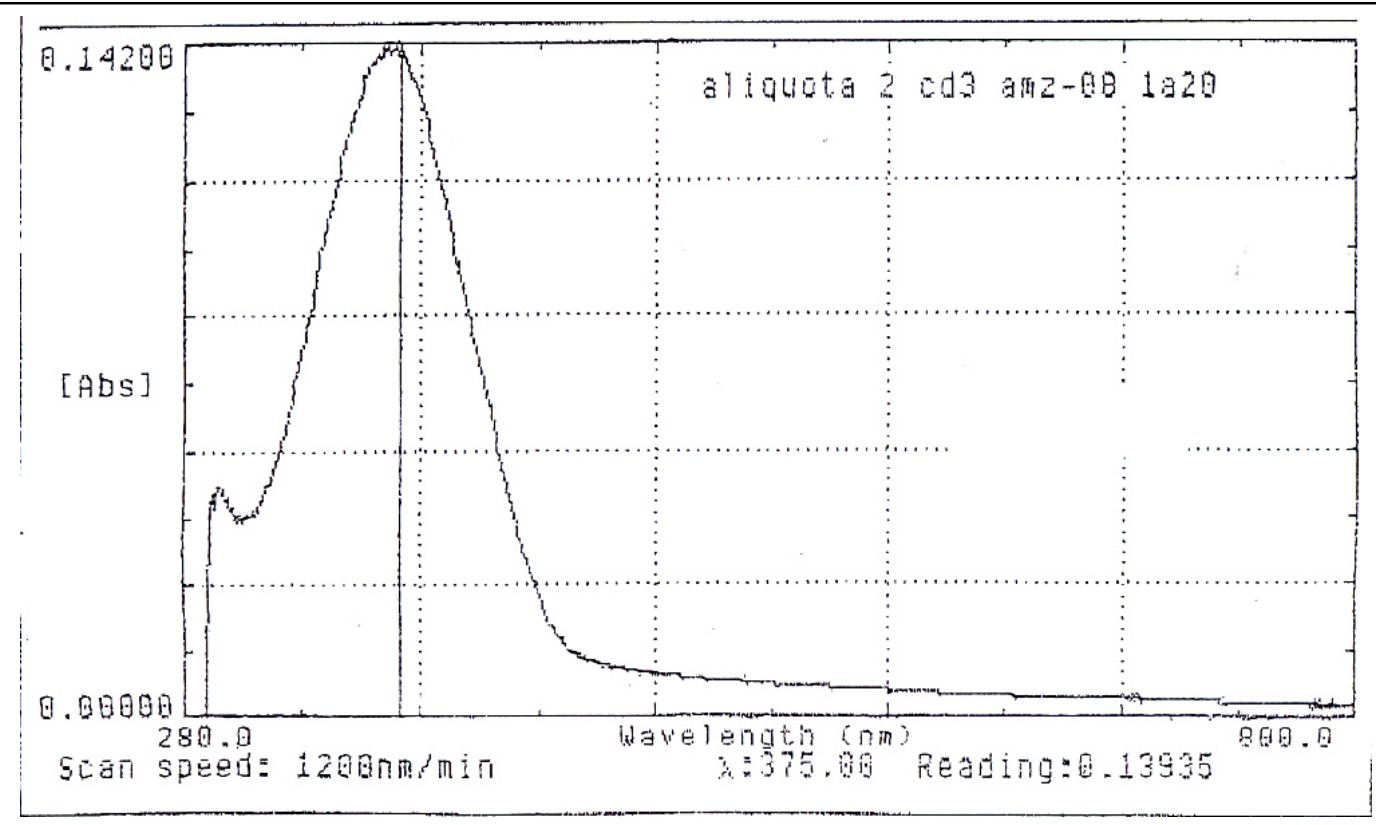

Figure 6S. Absorption spectrum of the conjugate of IgG1 isotype antibody with compound 9 ( $\mathrm{F} / \mathrm{P}=6.7$, dilution $1: 20)$ after stabilizing with $0.5 \% \mathrm{BSA} / 0.1 \%$ sodium azide $(\mathrm{w} / \mathrm{v})$. 


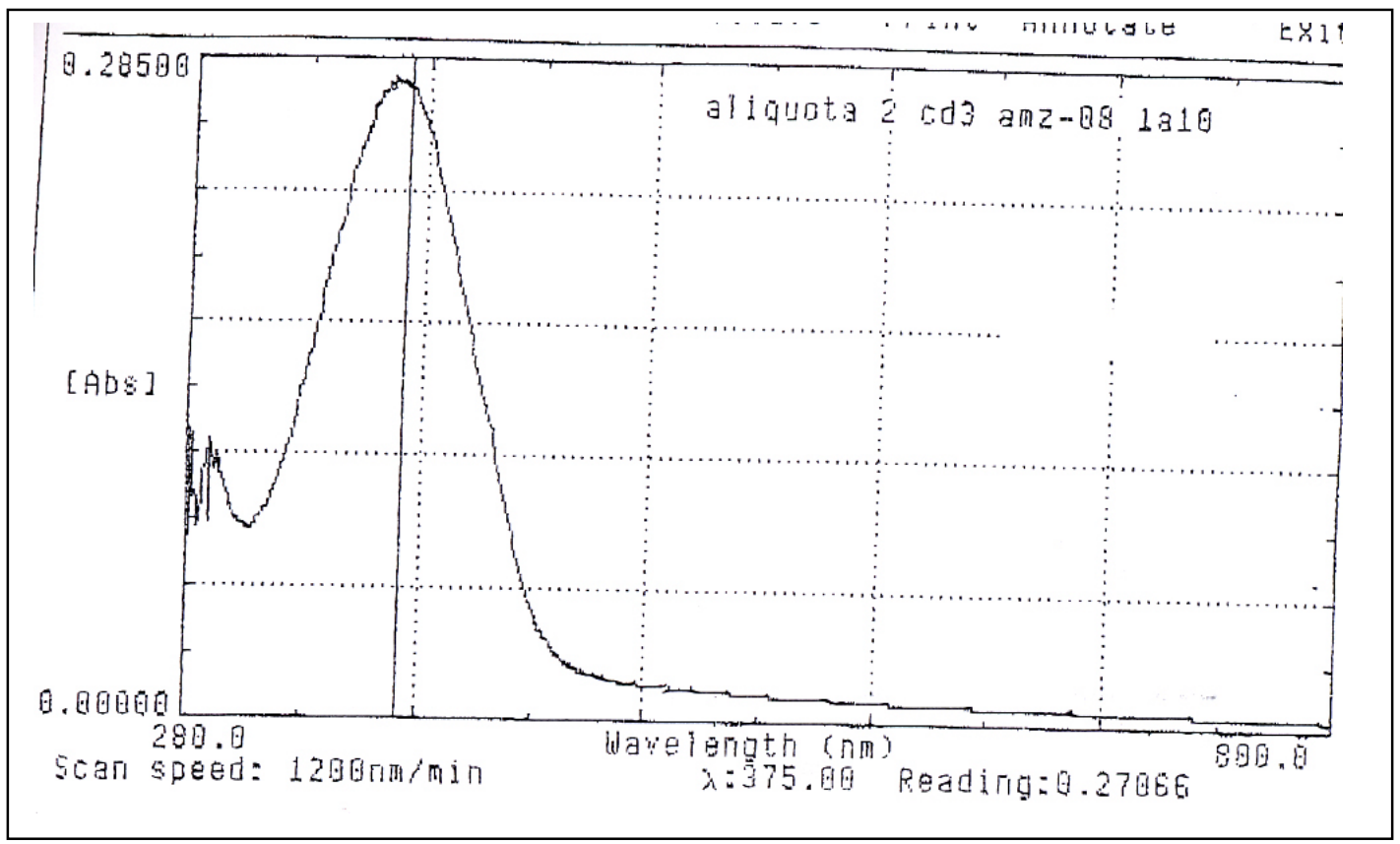

Figure 7S. Absorption spectrum of the conjugate of IgG1 isotype antibody with compound $\mathbf{9}$ ( $\mathrm{F} / \mathrm{P}=6.7$, dilution $1: 10)$ after stabilizing with $0.5 \% \mathrm{BSA} / 0.1 \%$ sodium azide $(\mathrm{w} / \mathrm{v})$. 


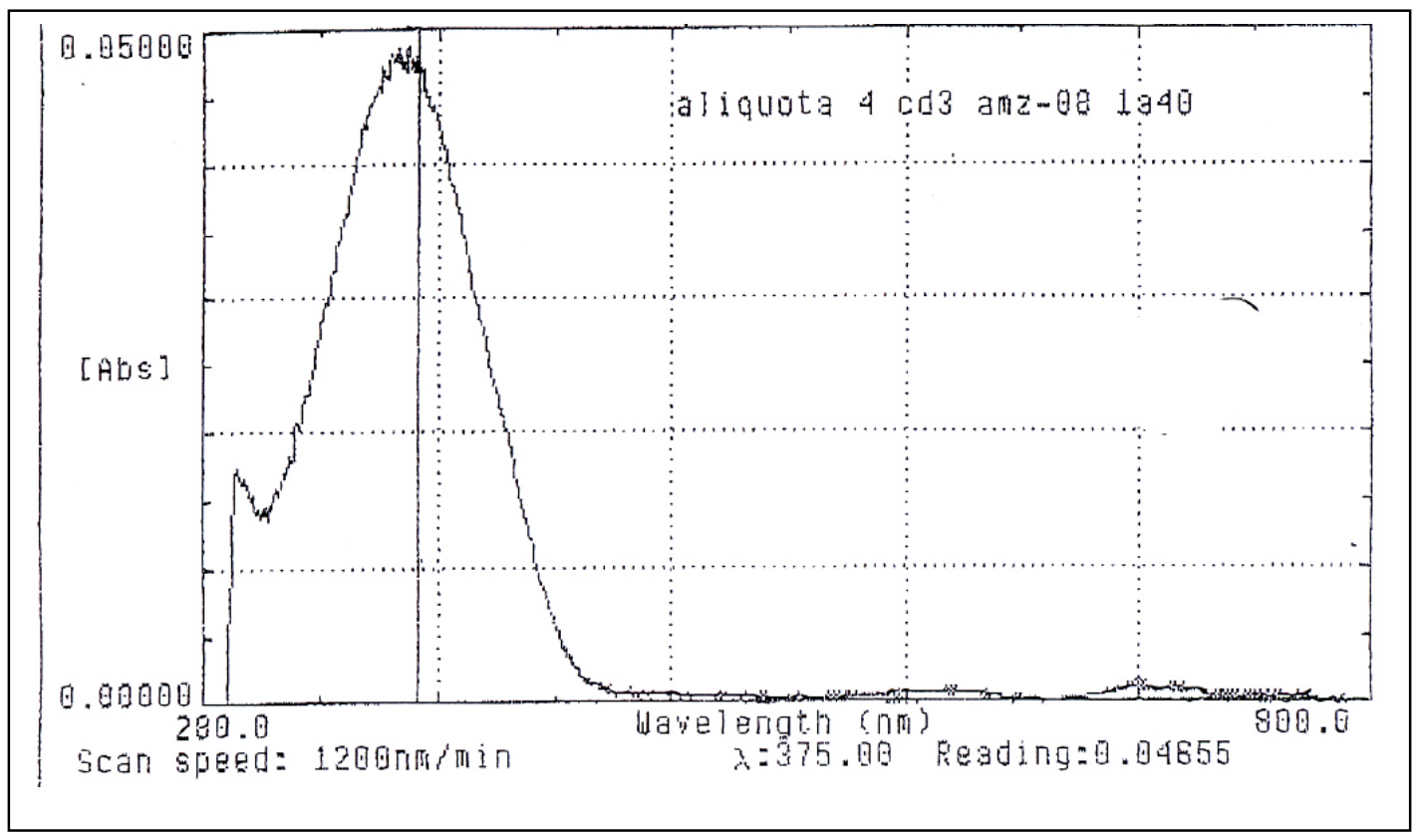

Figure 8S. Absorption spectrum of the conjugate of IgG1 isotype antibody with compound $\mathbf{9}$ $(\mathrm{F} / \mathrm{P}=2.5$, dilution $1: 40)$ after stabilizing with $0.5 \% \mathrm{BSA} / 0.1 \%$ sodium azide $(\mathrm{w} / \mathrm{v})$.

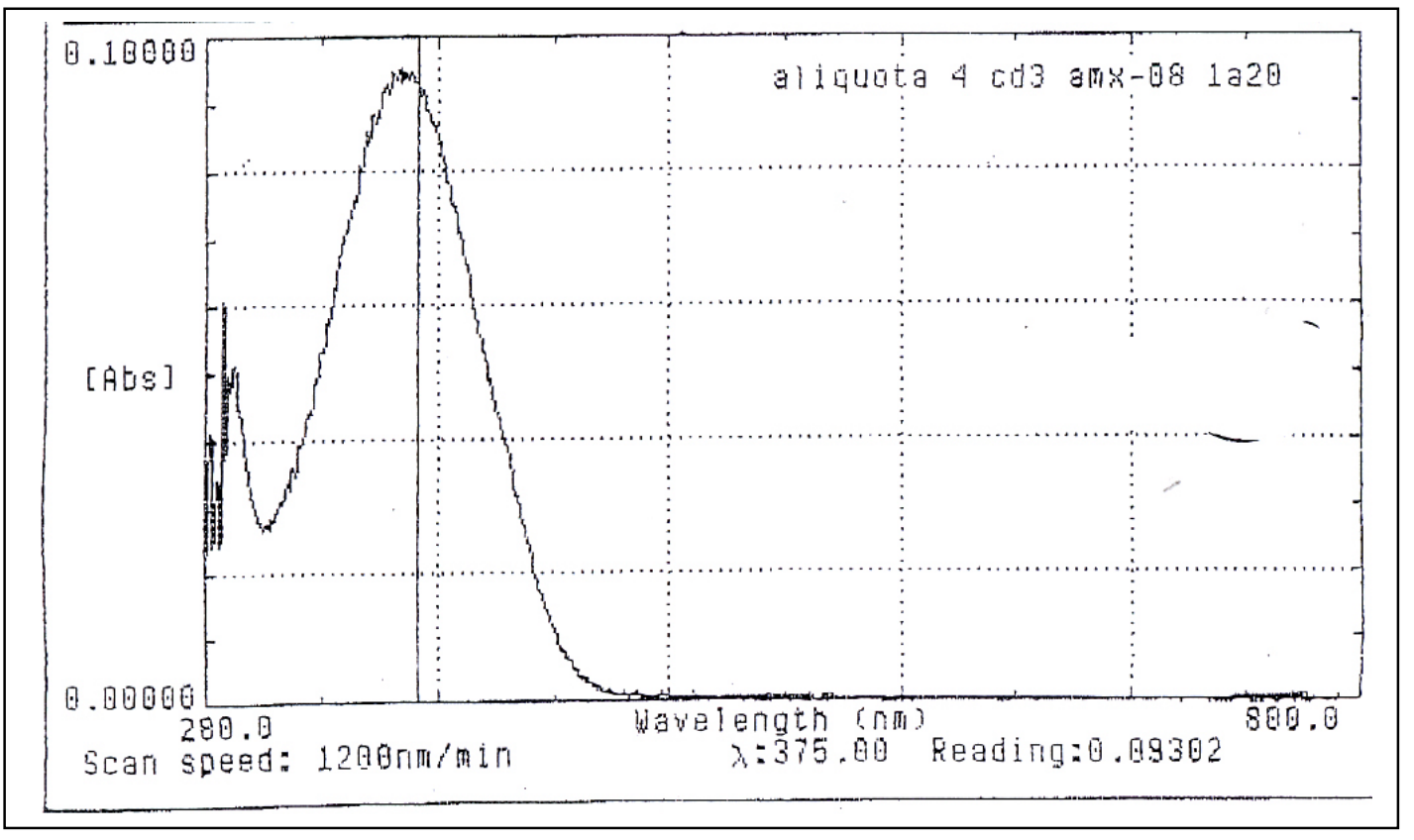

Figure 9S. Absorption spectrum of the conjugate of IgG1 isotype antibody with compound 9 $(\mathrm{F} / \mathrm{P}=2.5$, dilution $1: 20)$ after stabilizing with $0.5 \% \mathrm{BSA} / 0.1 \%$ sodium azide $(\mathrm{w} / \mathrm{v})$. 


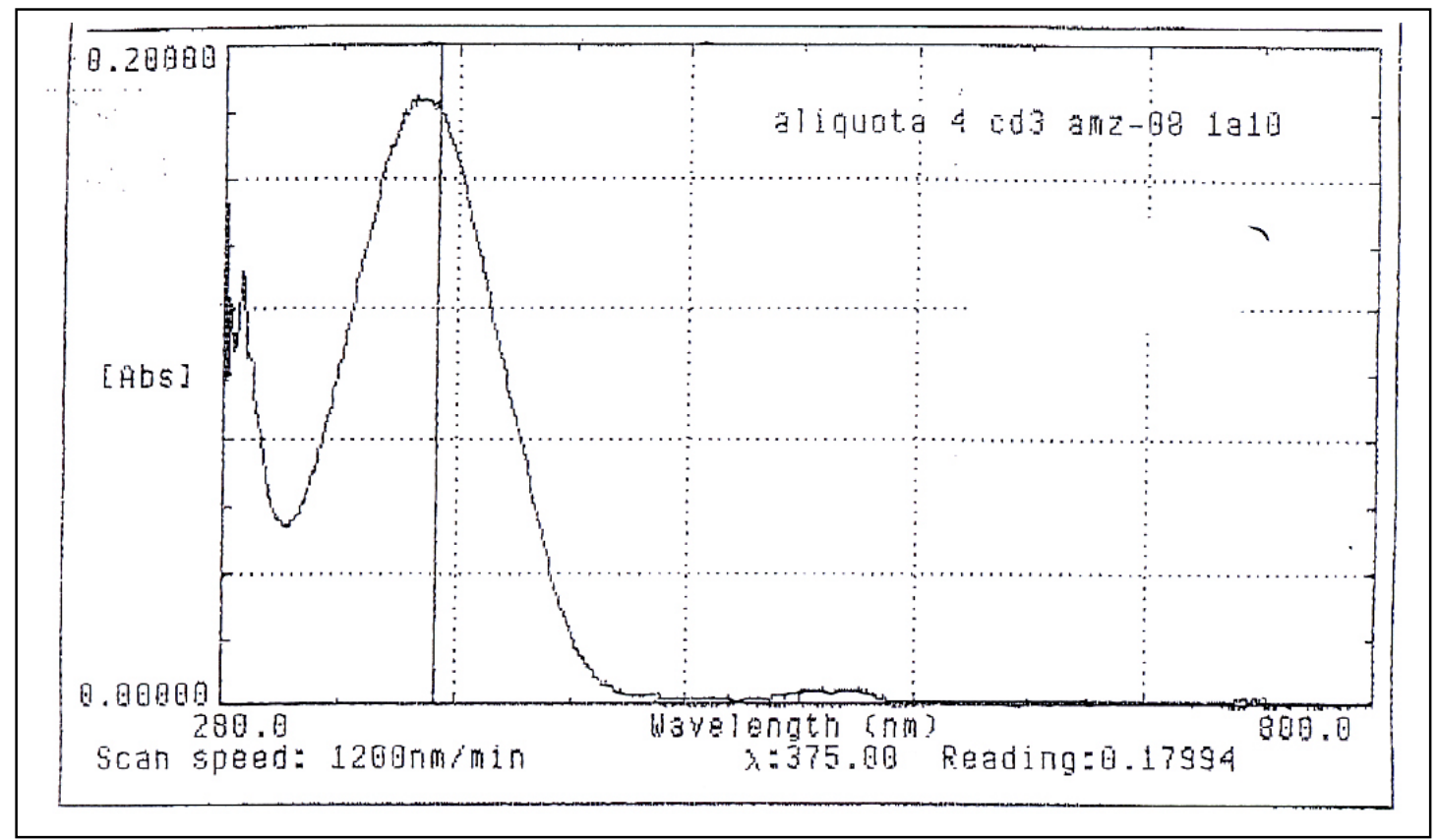

Figure 10S. Absorption spectrum of the conjugate of IgG1 isotype antibody with compound 9 ( $\mathrm{F} / \mathrm{P}=2.5$, dilution $1: 10)$ after stabilizing with $0.5 \% \mathrm{BSA} / 0.1 \%$ sodium azide $(\mathrm{w} / \mathrm{v})$. 


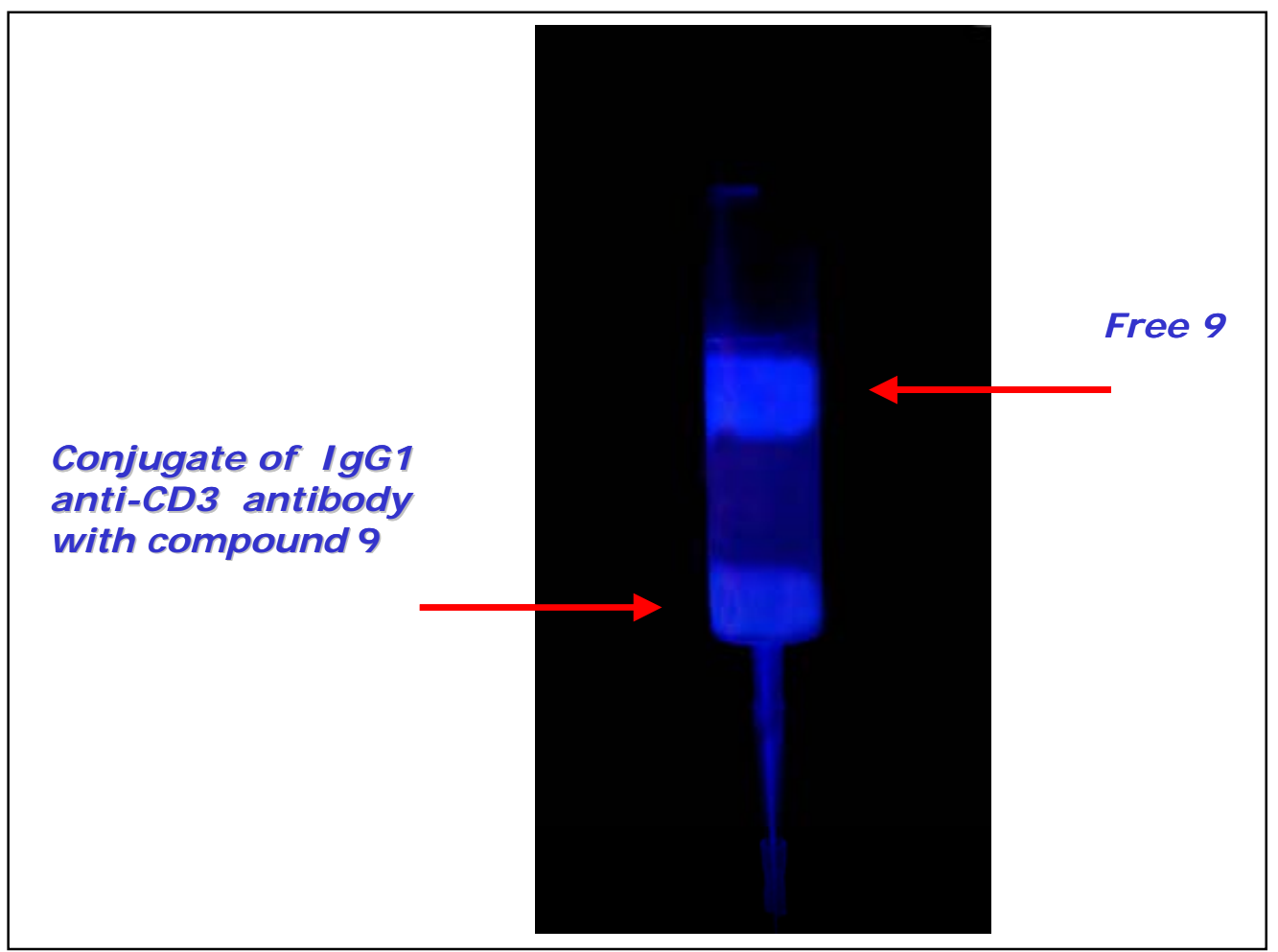

Figure 11S. Photograph of the separation of the conjugates of IgG1 isotype antibody with compound 9 from the free fluorophore by size exclusion chromatography under irradiation with a $15 \mathrm{~W}$ lamp at $\lambda_{\text {exc }}=364 \mathrm{~nm}$

\section{LITERATURE CITED}

(1) Rajagopalan, R., Kuntz, R. R., Sharma, U., Volkert, W. A., Pandurangi, R. S. (2002)

Chemistry of Bifunctional Photoprobes. 6. Synthesis and Characterization of High Specific Activity Metalated Photochemical Probes: Development of Novel Rhenium Photoconjugates of Human Serum Albumin and Fab Fragments. J. Org. Chem. 67, 6748-6757. 